\title{
PYROLISATOR COAL TO BE COKES (COAL COKES) CASTING METAL INDUSTRY STANDARD
}

\author{
Sukamto*, Didi Samanhudi, Sunardi, Nana Dyah Siswati. \\ University of Pembangunan Nasional "Veteran" Jawa Timur, Surabaya, East Java Indonesia \\ E-mail : kamtonep@gmail.com
}

\begin{abstract}
Pyrolisis of coal is partial combustion to reduce total moisture, volatile matter and sulfur contens and increase the calorific value of coal. The results of pyrolysis of coal is coke. At the laboratory level studies, pyrolisis done in batch using different calorie, namely $5800,6000,6300 \mathrm{kcal} / \mathrm{kg}$ and a time of $15-60$ minutes and the temperature $400-800^{\circ} \mathrm{C}$. Maximum results obtained total moisture $(0.44 \%)$, fixed carbon $(89 \%)$, volatile matter $(2.4 \%)$, sulfur content (undetected) and ash (7.2\%). Then applied to the scale miniplant with continuous processes using multitube pyrolisator which are designed to operate in the temperature range $400-800 \mathrm{oC}$ and a flow rate of $240-730 \mathrm{~kg} / \mathrm{h}$, obtained coal cokes that meets industry quality standards, namely TM (0.42\%), FC (90.40\%), VM (2.16\%), S (not detected), Ash (6.8\%) incalori 6300 kcal/h, a flow rate of $240 \mathrm{~kg} / \mathrm{h}$ and temperatures between $600-700^{\circ} \mathrm{C}$
\end{abstract}

Keywords: coal, coke, pyrolisis, solvenisasi, total moisture, fixed carbon, volatile matter, sulfur content.

\section{INTRODUCTION}

Utilization of coal as an alternative energy source Fuel needed considering Indonesia has coal reserves are enough. Of national coal production on average per year amounted to 131.72 million tons, which is used in the country is only 32.91 million tonnes / year, while the rest, as many as 92.5 million tons exported abroad (Pusdatin, 2014). The types of coal that exist in Indonesia, including anthracite by $0.4 \%, 14.4 \%$ bituminous, sub-bituminous $26.6 \%$, lignite amounted to $58.6 \%$, and the remainder in the form of peat. Utilization of coal used tend to be of high quality coal types of anthracite and bituminous because both have a high calorific value and if used continuously will make coal resources will be depleted. Therefore, researchers are working to increase the economic value of coal into coal cokes.By obtaining coal will reduce or as a substitute for imported that had been totally still imported.

Pyrolysis is the chemical decomposition process of coal by using heating in the absence of oxygen, in which the raw material will undergo breakdown of the chemical structure into the gas phase. In the pyrolysis process will be obtained in the form of solid residues which yield high carbon tar and oil and gas high levels of hydrogen to be used to convert into liquid fuel (Hidayat, 1995). Pyrolysis is a special case of thermolysis. In many industrial applications, the process is performed under pressure and operating temperatures above $430 \mathrm{oC}(806 \mathrm{oF})$ (Novitasari, W., 2015). In the pyrolysis of coal to produce gas feedstock such as $\mathrm{CO}, \mathrm{CO} 2, \mathrm{NOx}$, and SOx. Pyrolysis extremes, which only leaves a carbon residue, is called carbonization. Coal carbonization is the process of heating up the temperature and time (ranging from-above $200^{\circ} \mathrm{C}$ $1000^{\circ} \mathrm{C}$ in low oxygen conditions to remove the volatile matter content of the coal so that the resulting solids in the form of charcoal or cokes or semi cokes with tar and gas byproduct. Cokes produced is usually marketed as a domestic smokeless fuel which is produced in the form of a lump or powder containing $8-20 \%$ volatile matter (daf). Carbonization main function is to increase the calorific value, since the release of the water content, as well as the formation of tar that can function as a coating film that prevents re-absorption of water content.

The study aims to improve the quality of coal into cokes with quality standards industry and households, using coal pyrolisis process continuously in order to obtain optimum or maximum parameter and will generate pyrolisis products such as cokes, light gas, light oil and heavy oil. Parameters used as determinants of quality coal cokes is a total moisture (TM), fixed carbon (FC), volatile matter (VM), sulfur content (S) and Ash.

\section{METHODOLOGY}

\section{Materials and equipment}

Materials used in this study is coal that has a calorific value of 5800-6300 cal / kg, less glossy black compact, relatively high carbon content, water content, ash, and a little sulfur, obtained from Kalimantan. While the equipment used in this study is choper (crushers), pyrolisator multitube which has been equipped with temperature control, bucket elevators, and a condenser.

Solvenisasi process

Coal calori $5800 \mathrm{cal} / \mathrm{kg}, 6000 \mathrm{cal} / \mathrm{kg}$ and 6300 $\mathrm{cal} / \mathrm{kg}$, destroyed up to a size of $2-5 \mathrm{~cm}$, then soaked $1 \mathrm{~s} /$ d 2 hours with solvent Amoks Chem.04 at concentrations of $0.4 \%$, then dried to dry, so that the coal has been ready for use as a raw material to be used as a pyrolysis process.

\section{Pyrolysis process}

Coal (semi-coke) from the solvenisasi process weighing $200 \mathrm{~kg}$ fed into pyrolisator multitube, burned at the temperature varies $\left(400{ }^{\circ} \mathrm{C}, 500{ }^{\circ} \mathrm{C}, 600{ }^{\circ} \mathrm{C}, 700{ }^{\circ} \mathrm{C}\right.$, $\left.800^{\circ} \mathrm{C}\right)$, flow rate also varies $(240 \mathrm{~kg} / \mathrm{h}, 360 \mathrm{~kg} / \mathrm{h}, 540$ $\mathrm{kg} / \mathrm{h}, 730 \mathrm{~kg} / \mathrm{h}$ ).

\section{RESULT}

Table-1. Composition of the start of coal at various calorie

\begin{tabular}{|c|l|l|l|l|l|}
\hline \multirow{2}{*}{$\begin{array}{c}\text { Coal } \\
\text { calories } \\
(\mathbf{k c a l} / \mathbf{k g})\end{array}$} & \multicolumn{5}{|c|}{ Weight( \%) } \\
\cline { 2 - 6 } & TM & FC & VM & S & Ash \\
\hline 5800 & 11 & 41.2 & 43.18 & 0.7 & 4 \\
\hline 6000 & 10.60 & 41.30 & 39.00 & 0.9 & 6.4 \\
\hline 6300 & 10.80 & 43.42 & 38.85 & 0.9 & 6.02 \\
\hline
\end{tabular}

Results of analysis of total moisture of cokes in this study on a variety of variables stable, ranging from 0.4 to $0.6 \%$. 
Table-2. Fixed carbon( $\%$ ) various calorie coal and the temperature at a flow rate of $240 \mathrm{~kg} / \mathrm{h}$.

\begin{tabular}{|l|l|l|l|l|l|}
\hline \multirow{2}{*}{$\begin{array}{l}\text { Coal } \\
\text { calories } \\
(\mathbf{k c a l} / \mathbf{k g})\end{array}$} & 400 & 500 & 600 & 700 & 800 \\
\cline { 2 - 6 } & & & & & \\
\hline 5800 & 78.30 & 86.06 & 89.00 & 89.20 & 89.60 \\
\hline 6000 & 78.00 & 88.32 & 90.20 & 90.46 & 90.80 \\
\hline 6300 & 78.05 & 88.00 & 90.40 & 90.46 & 90.82 \\
\hline
\end{tabular}

Table-3. Levels of volatile matter(\%) various calorie coal and the temperature at a flow rate of $240 \mathrm{~kg} / \mathrm{h}$.

\begin{tabular}{|l|l|l|l|l|l|}
\hline \multirow{2}{*}{$\begin{array}{l}\text { Coal } \\
\text { calories } \\
(\mathbf{k c a l} / \mathbf{k g})\end{array}$} & \multicolumn{5}{|c|}{ Temperature $\left({ }^{\mathbf{}} \mathbf{C}\right)$} \\
\cline { 2 - 6 } & 400 & 500 & 600 & 700 & 800 \\
\hline 5800 & 17.01 & 7.8 & 3.80 & 2.9 & 2.2 \\
\hline 6000 & 16.2 & 5.80 & 3.42 & 2.40 & 2.32 \\
\hline 6300 & 16.02 & 6.40 & 3.60 & 2.39 & 2.32 \\
\hline
\end{tabular}

Results of analysis of sulfur content of various types of calories, the temperature and the flow rate of cokes, undetected.

Table-4. Ash content (\%) of various calorie coal and the temperature at a flow rate of $240 \mathrm{~kg} / \mathrm{h}$

\begin{tabular}{|l|l|l|l|l|l|}
\hline \multirow{2}{*}{$\begin{array}{l}\text { Coal } \\
\text { calories } \\
(\mathbf{k c a l} / \mathbf{k g})\end{array}$} & 400 & 500 & 600 & 700 & 800 \\
\cline { 2 - 6 } & & & & & \\
\hline 5800 & 4.60 & 6.14 & 6.70 & 7.40 & 7.70 \\
\hline 6000 & 5.80 & 5.88 & 5.88 & 6.68 & 6.38 \\
\hline 6300 & 5.90 & 5.60 & 5.50 & 6.65 & 6.36 \\
\hline
\end{tabular}

\section{DISCUSSION}

The results obtained from this study compared to the composition of the coking coal industry standards, to determine whether eligible or not.

Table-5. The composition of cokes for Standard Industry

\begin{tabular}{|c|l|c|}
\hline No & \multicolumn{1}{|c|}{ Parameter } & \% Berat \\
\hline 1 & Total Moisture (TM), max & 1 \\
\hline 2 & Fixed Carbon (FC), min & 85 \\
\hline 3 & Volatile Matter (VM), max & 2.38 \\
\hline 4 & Sulfur Content (S), max & 0.01 \\
\hline 5 & Ash, max & 12 \\
\hline
\end{tabular}

When compared to the industry standard coking coal as shown in Table 5 , the results of which are eligible are in calories $6300 \mathrm{kcal} / \mathrm{kg}$, between $600-700^{\circ} \mathrm{C}$ temperature and flow rate of $240 \mathrm{~kg} / \mathrm{h}$. The lowest flow rate allows a long contact time resulting in more complete combustion than at high flow rates (short contact time).

\section{Total Moisture (TM)}

As it is known that the water damp or moisture (moisture) is regarded as one of the impurity (impurity or a diluent) were just as ash in the coal that is forming components of coal which can not be burnt (being incombustible) so as to lower the commercial value in the form of parameter values calories (calorific value $=\mathrm{CV}$ ). Therefore, the effect on the quality of coal must be strictly controlled in order to be sold (salable coal) as a result of the levels that have met the requirements or specifications of coal demanded by the market or consumer. (timorhauniarain, 2013).

\section{Fixed carbon (FC)}

Fixed carbon is the fixed carbon contained in the coal after volatile matters separated. Shown in Table 2 , the fixed carbon in the cokes produced, the greater as the calorific value of coal used, this is in accordance with Indah, 2009, that the value of the carbon content is increasing along with the increasing quality of the coal.

\section{Volatile Matter (VM)}

Volatile Matter is a compound in a volatile coal at a certain temperature under standard conditions. Results of analysis of volatile matter in cokes as shown in Table 3, the greater the calorie coal and the higher the combustion temperature, the volatile matternya getting smaller, it is because the volatile matter is that many substances that are lost when the coal sample is heated at a temperature and a predetermined time (after corrected with moisture content). Factors affecting the results of the determination of volatile matter the temperature, time, velocity, warming, the spread of grain and particle size (Simorangkir, T., 2013). Volatile matter is used as a measure of the quality of coal (Palupi, I., 2012). The higher the coal rank, the lower the levels of volatile matternya (Indra, 2015).

\section{Sulfur Content (S)}

Results of analysis of sulfur at various variables is not detected, because sulfur is converted to sulfur oxides during the combustion process that can cause corrosion and scaling of equipment also causes air pollution. Sulfur is used for the evaluation of the use of coal combustion (Palupi, I., 2012).

\section{Ash Content (ash)}

Shown in Table 4, that the greater the calorie coal, the ash content produced smaller, or conversely the lower calorie coal, the higher ash content, which is in line with Rismayanti, 2012, that the higher the ash content in the coal type the same, the low caloric value.

\section{Applications on a scale miniplant}

For miniplant scale coke production process has been carried out at the optimal operating conditions according to the results of research namely the use of coal $6300 \mathrm{kcal} / \mathrm{kg}$ in pyrolisis at temperatures between 600 $700^{\circ} \mathrm{C}$ and a flow rate of $240 \mathrm{~kg} / \mathrm{h}$. Process equipment designed by the researchers, is designed on a small scale with supporting equipment (auxilang equipment) as buchet elevators, condensor and blower as gas suction. Equipment and supporting the scheme shown in Figure 1. 


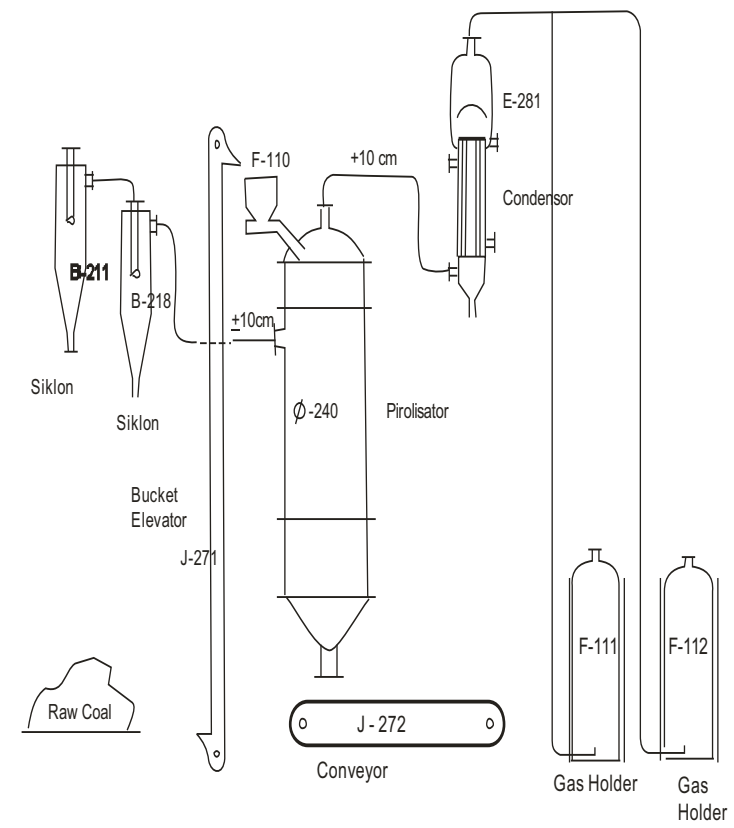

Figure-1. Diagram of the industry process of cokes

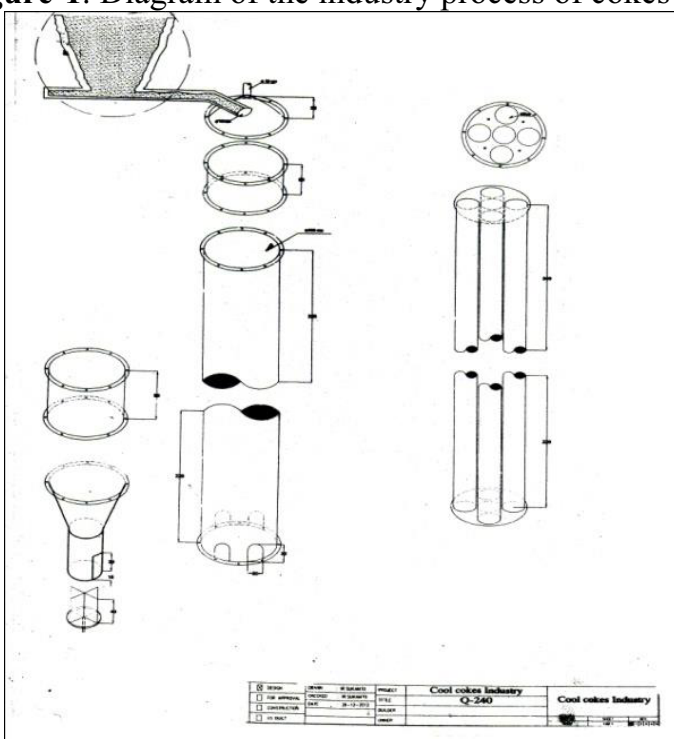

Figure-2. Design of the multi tube pyrolisator

Table-6. Specification of equipment :

\begin{tabular}{|c|c|c|}
\hline No & Name & Size \\
\hline 1. & Disc Head & $\begin{array}{l}\text { Stainliess steel } 3063 \mathrm{~mm} \\
\text { thick. } Q=80 \mathrm{~cm}, 45{ }^{\circ} \text { tilt } \\
\text { angle, and height } 20 \mathrm{~cm} .\end{array}$ \\
\hline 2. & $\begin{array}{l}\text { Tube } \\
\text { evaporation } \\
\text { zone }\end{array}$ & $\begin{array}{l}\text { Steinliess steel } 3063 \mathrm{~mm} \\
\text { thick. } Q=80 \mathrm{~cm} \text {, height } 20 \mathrm{~cm} .\end{array}$ \\
\hline 3. & $\begin{array}{l}\text { Furnace tube } \\
\text { Pyrolisator }\end{array}$ & $\begin{array}{l}\text { Stainliess steel } 3063 \mathrm{~mm} \\
\text { thick. } Q=80 \mathrm{~cm} \text {, height } 20 \\
\mathrm{~cm} \text {. } \\
\text { - Gas stove } 4 \text { units with } \\
\text { specifications } 50000- \\
150000 \text { calories } / \mathrm{kg} \\
\text { - Isolator } \pm 160 \mathrm{~m} \text { of asbestos } \\
\text { and gypsum. }\end{array}$ \\
\hline 4. & $\begin{array}{l}\text { Temperature } \\
\text { control }\end{array}$ & $\begin{array}{l}\text { Digital temperature control } \\
\text { with a temperature range up to } \\
1100 \text { o C. }\end{array}$ \\
\hline 5. & $\begin{array}{l}\text { Pipe (tube) } \\
\text { pyrolisator }\end{array}$ & $\begin{array}{l}\text { Stainless steel } 306 \text {, unit } 5 \text {, } \\
\text { pipes } \propto 4 \text { ", height } 240 \mathrm{~cm}\end{array}$ \\
\hline
\end{tabular}

\begin{tabular}{|l|l|l|}
\hline 6. & $\begin{array}{l}\text { Tube cooling } \\
\text { zone }\end{array}$ & $\begin{array}{l}\text { - Stainliess steel } 306 \quad \mathrm{~mm} \\
\text { thick. } Q=80 \mathrm{~cm} \text {, height } 60 \\
\text { mm. } \\
\text { - Conical stainless steel } 3063 \\
\text { mm thick. } \\
\text { - Discharge pipe stainless } \\
\text { steel 306, equipped with } \\
\text { screw discharge angle of } \\
45 \mathrm{o} Q 8 \mathrm{".}\end{array}$ \\
\hline 7. & Motor Drive & Power $1.5 \mathrm{hp}, 1800 \mathrm{rpm}$ \\
\hline 8. & Reducer gear 30 & $\begin{array}{l}\text { Rpm regulator equipped with } \\
\text { pully }\end{array}$ \\
\hline 9. & Bucket Elevator & Height $6.30 \mathrm{~cm}$. \\
\hline 10. & Condensor & \\
\hline 11. & Gas Holder & \\
\hline
\end{tabular}

Results of analysis of the coke production process, the obtained coke that meets industry standards, as shown in Table 7.

Table-7. Composition of cokes mini-plant scale at a flow rate of $240 \mathrm{~kg} / \mathrm{h}$ and temperatures between $600-700^{\circ} \mathrm{C}$.

\begin{tabular}{|l|c|c|c|}
\hline \multirow{2}{*}{ Parameter } & \multicolumn{3}{|c|}{ Coal calorie (kcal/kg) } \\
\cline { 2 - 4 } & $\mathbf{5 8 0 0}$ & $\mathbf{6 0 0 0}$ & $\mathbf{6 3 0 0}$ \\
\hline TM max & 0.43 & 0.40 & 0.42 \\
\hline FCmax & 89.02 & 90.2 & 90.40 \\
\hline VM max & 2.56 & 2.37 & 2.16 \\
\hline S max & undetected & undetected & undetected \\
\hline Ash, max & 7.2 & 9.80 & 6.80 \\
\hline
\end{tabular}

\section{CONCLUSIONS}

Research that has been carried out, showing that optimum results in the treatment of variables 6300 calories, a flow rate of $240 \mathrm{~kg} / \mathrm{h}$ and temperatures between $600-700 \mathrm{oC}$ with a Total Moisture $0.42 \%$, Fixed Carbon $90.40 \%$, Volatile Matter 2.16\%, Sulfur Content undetected and $6.8 \%$ Ash. Pyrolisator multitube goes well, by adjusting the operating conditions of temperature and flow rates have been determined. Capacity and quality can be maintained so that the products cokes meet the standard metal casting industry or can be used as a chemical industry to another.This study of the data obtained and the phenomena that occur (at temperatures of $700^{\circ} \mathrm{C}$ and $800^{\circ} \mathrm{C}$ ), required a more adequate planning, especially at the rate of condensation

\section{REFERENCES}

Andre, A., 2012. Analysis of samples of coal from South Sumatra. Chemical Analysis Program of Bogor Agricultural Diploma program.

Anonymous, 2008. Coal-alternative-energy-replacement, Semarangantenan.blogspot.com

Anonymous, 1999. Coal, www.scribd.com

Anonymous, 2012. Literature-materialism Inorganic-InCoal, www.scribd.com

Anonymous, 2013.http://www.alpensteel.com/article/51113-energi-lain-lain/2336--reserve-fuel-oil-diminish.html

Bayuseno, A.P.2009. Effect of Physical Properties and Structure of the Local Mineral Coal Combustion 
properties. Faculty of Engineering, University of Diponegoro, bosstambang.com

Hadijah, NR and Damayanti, R., 2006. Research Abu coal as Pembenah Land, Mineral and Coal Technology Journal, No. 36, Year 14, January 2006

Idhamds, 2008. Analysis of coal. idhamds.wordpress.com Indah, 2009. Analysis of coal quality. indah4din4t4.wordpress.com

Indra, 2015. The coal quality parameters. www.academia.edu.

Kadir, A., 2010. Energy. Publisher University of Indonesia (UI Press), third edition.

Narozana, 2009. Preparation of liquid smoke by pyrolysis method. asapcairsebagaipengawet.blogspot.com

Novitasari, W., 2015. Pyrolysis. www.academia.edu Palupi, I., 2012. The analysis of coal samples. irlandapalupi.blogspot.com/2012/03/analisa-samplebatubara.html.
Putrago, 2009. Definition-resource-and-reserve coal, putrago.blog.akprind.ac.id

Sari, NL, 2009. Potential of Coal Indonesia. Journal of Environment, ed. August 2009, uwityangyoyo.wordpress.com/tag/batubara

Simorangkir, TA, 2013. Proximate Analysis, Ultimate Analysis and Miscellaneous Analysis on coal. Mineral Mining Engineering Faculty of Technology Institute of Technology Medanta.

Soetjijo, H.2004. Low Levels of Coal Quality Improvement (Upgrading Low Grade Coal). Research Centre for Geotechnology - LIPI

Suganal, 2009. Coal Briquette Making Process Design nonkarbonisasi small scale of High ash coal. Mineral and Coal Technology Journal, Volume 5, Number 13, January 2009. ISSN 1979-6560

Timorhauniarain, 2013. Characterization of coal quality). timorhauniarain.blogspot.com (2013). 